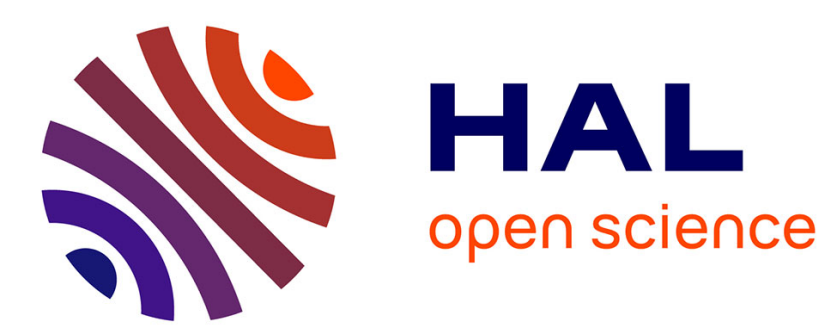

\title{
Estimation of stomatal ozone uptake of deciduous trees in East Asia
}

Hoshika, Hajima, Shimizu, Takigawa, Omasa

\section{To cite this version:}

Hoshika, Hajima, Shimizu, Takigawa, Omasa. Estimation of stomatal ozone uptake of deciduous trees in East Asia. Annals of Forest Science, 2011, 68 (3), pp.607-616. 10.1007/s13595-011-0051-9 . hal-00930786

\section{HAL Id: hal-00930786 \\ https://hal.science/hal-00930786}

Submitted on 1 Jan 2011

HAL is a multi-disciplinary open access archive for the deposit and dissemination of scientific research documents, whether they are published or not. The documents may come from teaching and research institutions in France or abroad, or from public or private research centers.
L'archive ouverte pluridisciplinaire HAL, est destinée au dépôt et à la diffusion de documents scientifiques de niveau recherche, publiés ou non, émanant des établissements d'enseignement et de recherche français ou étrangers, des laboratoires publics ou privés. 


\title{
Estimation of stomatal ozone uptake of deciduous trees in East Asia
}

\author{
Yasutomo Hoshika • Tomohiro Hajima • Yo Shimizu • \\ Masayuki Takigawa $\cdot$ Kenji Omasa
}

Received: 30 March 2009/Accepted: 12 October 2010/Published online: 20 April 2011

(C) INRA and Springer Science+Business Media B.V. 2011

\begin{abstract}
- Background To assess ozone risks to temperate deciduous forest trees in East Asia, the stomatal ozone uptake was estimated based on a flux-based modeling approach. - Methods In this model, key parameters were obtained from scientific literatures on deciduous tree species in East Asia. In addition, regional characteristics of the leaf duration were estimated using a phenological model.

- Results The result showed a difference in spatial pattern between $\mathrm{AF}_{\mathrm{st}} \mathrm{O}$ (accumulative stomatal ozone uptake) and AOT40 (accumulative exposure above a threshold concentration of $40 \mathrm{ppb}$ during daylight hours). Although most of the areas of high ozone concentration corresponded to humid climate areas, not only the ozone concentration, but also the length of the leaf duration and the species-specific stomatal response to environmental factors, limited $\mathrm{AF}_{\mathrm{st}} \mathrm{O}$ in East Asia.

- Conclusion These results suggested that an approach based on stomatal ozone uptake would be a useful tool for ozone risk assessment in East Asia.
\end{abstract}

\footnotetext{
Handling Editor: Erwin Dreyer

Y. Hoshika $\cdot$ Y. Shimizu $\cdot$ K. Omasa $(\bowtie)$

Graduate School of Agricultural and Life Sciences,

The University of Tokyo,

1-1-1 Yayoi, Bunkyo-ku,

Tokyo 113-8657, Japan

e-mail: aomasa@mail.ecc.u-tokyo.ac.jp

T. Hajima $\cdot$ M. Takigawa

Frontier Research Center for Global Change, Japan Agency

for Marine-Earth Science and Technology,

3173-25 Showamachi,

Yokohama 236-0001 Kanagawa, Japan
}

Keywords Deciduous forest trees · Ozone uptake modeling $\cdot$ Stomatal conductance $\cdot$ East Asia

\section{Introduction}

The phytotoxic nature of ozone has been well-known for decades (e.g., NIES 1980, 1984). Surface ozone concentrations are increasing in East Asia because of rapid increases in emissions of the main critical ozone precursors, $\mathrm{NO}_{\mathrm{x}}$ and volatile organic compounds (Naja and Akimoto 2004). Therefore, current ozone impacts on crops and forests have become very significant in East Asia (Ashmore 2005).

In Japan, the effects of ozone on the growth of forest tree species have been investigated by using AOT40 values, which represent accumulative exposure above a threshold concentration of $40 \mathrm{ppb}$ during daylight hours (e.g., Izuta et al. 2001; Kohno et al. 2005). An assessment approach using AOT40 has the advantage of being simple, because only atmospheric ozone concentration data are needed. However, ozone damage to plants depends not only on atmospheric ozone concentrations but also on stomatal ozone uptake into leaves. Previously, several studies suggested that stomatal ozone uptake was closely related to ozone damage (e.g., Omasa et al. 2002; Paoletti and Manning 2007). For this reason, a stomatal flux-based approach using stomatal ozone uptake was expected to provide better assessments of ozone damage to plants in Europe (Emberson et al. 2007). Critical levels for ozone risk using the stomatal flux-based indices were set for potato and wheat, and provisionally for sensitive forest species (beech, birch) (UNECE 2004). Furthermore, Karlsson et al. (2007) reported that the stomatal flux-based indices were superior to AOT40 for 
ozone-sensitive species, based on their reanalysis of published ozone exposure-response data.

Although the stomatal flux-based approach has been used in Europe, very little has been done to develop its use for assessing ozone damage to plants in East Asia. Therefore, our main objective in this study was to estimate stomatal ozone uptake for temperate deciduous forest trees in East Asia.

To do this, key parameters were needed for major species representative of different regions in East Asia. In addition, an assessment of leaf duration (the length of time a plant bears leaves) was needed for the model because in deciduous trees, ozone is taken up through stomata only during the leaf duration. This feature has been accounted for in previous AOT40 approaches by using a fixed time period (April September). However, an application of a simple assumption (i.e., a fixed time period for leaf duration) could be problematic, because the leaf duration varies among regions (Estrella and Menzel 2006).

In this study, we developed a model of accumulative stomatal ozone uptake $\left(\mathrm{AF}_{\mathrm{st}} \mathrm{O}\right)$, and applied it to assess $\mathrm{AF}_{\mathrm{st}} \mathrm{O}$ for deciduous forest trees in East Asia. The differences in spatial patterns between $\mathrm{AF}_{\mathrm{st}} \mathrm{O}$ and AOT40 were then assessed.

\section{Materials and methods}

\subsection{Stomatal conductance model}

Leaf-level stomatal conductance of water vapor $\left(\mathrm{g}_{\mathrm{sw}}\right)$ was estimated using the multiplicative model (Jarvis 1976; Emberson et al. 2007):

$g_{\text {sw }}=g_{\max } \cdot f_{\text {phen }} \cdot f_{\text {light }} \cdot \max \left\{f_{\min },\left(f_{\text {temp }} \cdot f_{V P D} \cdot f_{S M D}\right)\right\}$

where $g_{\max }$ is the maximum stomatal conductance. The other functions are limiting factors of $g_{\max }$ and are scaled from 0 to $1 . f_{\min }$ is the minimum stomatal conductance, and is set to 0 in this study. $f_{\text {phen }}$ is the variation in stomatal conductance with leaf age, and $f_{\text {light }}, f_{\text {temp }}, f_{\mathrm{VPD}}$, and $f_{\mathrm{SMD}}$ are functions of photosynthetically photon flux density at the leaf surface (PPFD, $\mu$ mol photons $\mathrm{m}^{-2} \mathrm{~s}^{-1}$ ), temperature $\left(\mathrm{T},{ }^{\circ} \mathrm{C}\right)$, vapor pressure deficit (VPD, $\mathrm{kPa}$ ), and volumetric soil water content $\left(\theta, \mathrm{m}^{3} \mathrm{~m}^{-3}\right)$ respectively.

The variation in stomatal conductance with leaf age $\left(f_{\text {phen }}\right)$ modifies $g_{\max }$ as a function of time within the leaf duration (Emberson et al. 2007). Maruyama and Honda (1993) reported that potential $g_{\mathrm{sw}}$ for temperate deciduous forest tree species varied from season to season, and they divided the seasonal variation of potential $g_{\mathrm{sw}}$ into three stages: (1) potential $g_{\text {sw }}$ started low and increased from leaf onset until full leaf expansion, (2) potential $g_{\text {sw }}$ was then high and remained almost constant during the leaf maturation period, and (3) potential $g_{\mathrm{sw}}$ decreased during leaf senescence in autumn. They also reported that it took about 1 month for $g_{\text {sw }}$ to reach its peak from leaf onset, and to decline due to its senescence until leaf fall. Therefore, we assumed that $f_{\text {phen }}$ increased linearly from 0 to 1 during the first 30 days after leaf onset, and decreased linearly from 1 to 0 during the 30 days prior to leaf fall.

The functions based on PPFD, T and VPD ( $f_{\text {light }}, f_{\text {temp }}$ and $f_{\mathrm{VPD}}$, respectively) have been expressed in various forms (e.g., Jarvis 1976; Sirisampan et al. 2003; Emberson et al. 2007). In this study, formulas for these functions were selected because they have been frequently used in modeling studies in East Asia (e.g., Sirisampan et al. 2003). These functions are expressed as follows:

$f_{\text {light }}=\frac{P P F D}{\left(P P F D+f_{\text {light_ } 0.5}\right)}$

$f_{\text {temp }}=\left(\frac{\mathrm{T}-T_{\min }}{T_{\mathrm{opt}}-T_{\min }}\right)\left\{\left(\frac{T_{\max }-\mathrm{T}}{T_{\max }-T_{\mathrm{opt}}}\right)^{\left(\frac{T_{\max }-T_{\mathrm{opt}}}{T_{\mathrm{opt}}-T_{\min }}\right)}\right\}$

$f_{V P D}=\frac{1}{\left(1+\left(V P D / f_{V P D \_} 0.5\right)^{a}\right)}$

where $f_{\text {light } \_.5}$ is the value of PPFD when $f_{\text {light }}=0.5$, and $T_{\text {opt }}, T_{\min }$, and $T_{\max }$ represent the optimum, minimum, and maximum temperatures for stomatal conductance respectively. $f_{\mathrm{VPD}} 0.5$ is the value of $\mathrm{VPD}$ when $f_{\mathrm{VPD}}=0.5$, and $a$ is a constant. Figure 1 shows a plot of these functions in the stomatal conductance model.

Table 1 lists the parameters used in the stomatal conductance model. Parameters of $f_{\text {light }}, f_{\text {temp }}, f_{\mathrm{VPD}}$, and $g_{\text {max }}$ were determined from a review of scientific literature on stomatal conductance of temperate deciduous forest tree species in East Asia. We collected parameters for the dominant species in each forest type. Temperate deciduous forest tree species were classified into three forest types within two climatic zones (cool-temperate and warmtemperate zones) in East Asia (Nakashizuka and Iida 1995). The forest types "cool-temperate mixed broadleaf/ conifer forest" (CMF) and "cool-temperate deciduous forest" (CDF) were distributed in the cool-temperate zone. CDF was unique to central Japan, which has a humid climate throughout the year, and heavy snow in winter. In the CDF region, beech (Fagus crenata) was the dominant 
Fig. 1 Plots of the functions $f_{\text {light }}(\mathbf{a}), f_{\text {temp }}(\mathbf{b})$, and $f_{\mathrm{VPD}}(\mathbf{c})$ of the stomatal conductance model when parameter values were altered. $f_{\text {light }}, f_{\text {temp }}$, and $f_{\mathrm{VPD}}$ are functions of photosynthetically photon flux density at the leaf surface (PPFD, $\mu \mathrm{mol}$ photons $\mathrm{m}^{-2} \mathrm{~s}^{-1}$ ), temperature $\left(\mathrm{T},{ }^{\circ} \mathrm{C}\right)$, and vapor pressure deficit (VPD, $\mathrm{kPa}$ ) respectively a

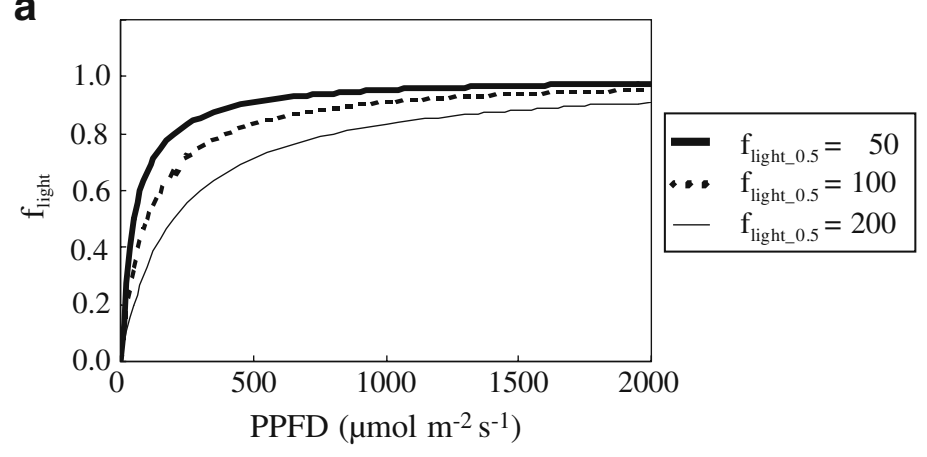

b

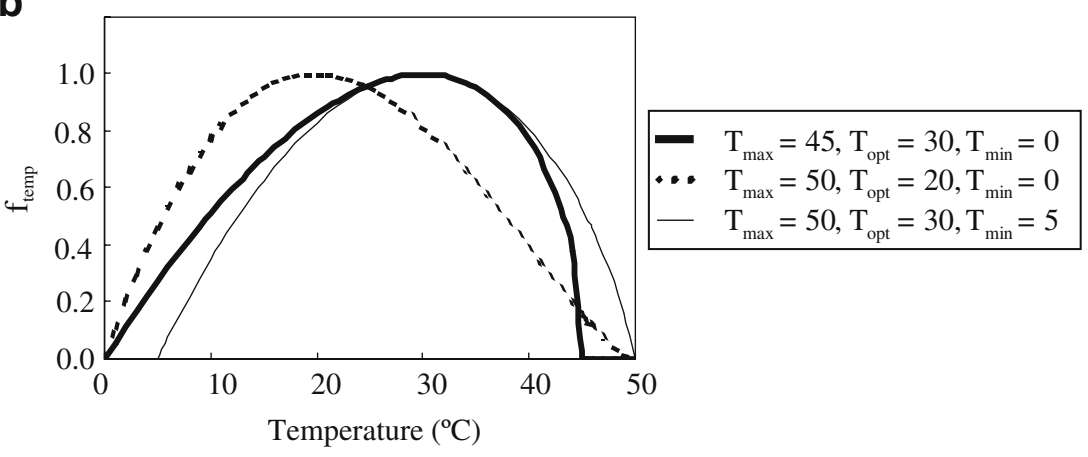

C

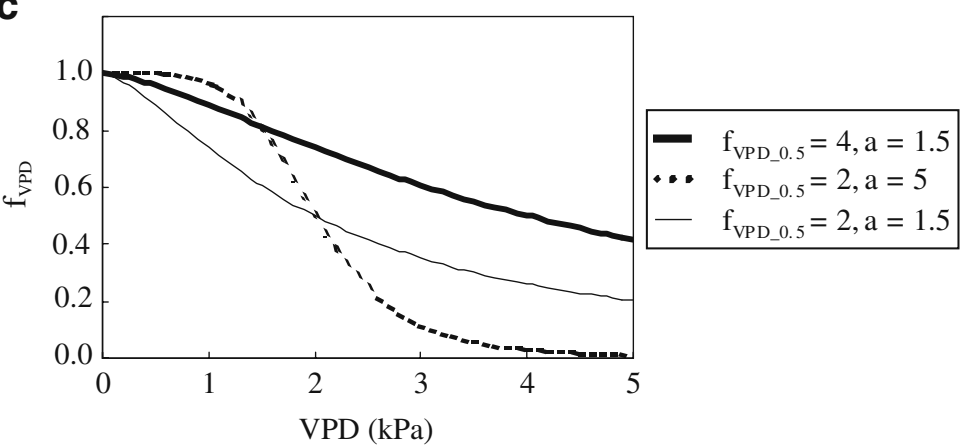

species. The CMF forest type was dominated by deciduous oak (mainly Quercus crispula and Quercus mongolica), with birch (Betula Ermanii) as a secondary species. In the warm-temperate zone, the forests were classified as "warm-temperate deciduous forest" (WDF), dominated by deciduous oak (e.g., Quercus serrata and Quercus liaotungensis).

As shown in Table 1, the parameters of the stomatal conductance model differed by species within the same climate region. For example, $Q$. crispula (CMF) has a $g_{\max }$ of $385 \mathrm{mmol} \mathrm{m}^{-2} \mathrm{~s}^{-1}$, whereas $B$. ermanii has a $g_{\max }$ of $680 \mathrm{mmol} \mathrm{m} \mathrm{m}^{-2} \mathrm{~s}^{-1}$. These characteristics of stomatal conductance parameters in each species would also affect the relationship between estimated stomatal ozone uptake and AOT40. (This point is discussed in Results section 3.3.)

Parameters of $f_{\mathrm{SMD}}$ could not be included in the model because of insufficient published data about $f_{\mathrm{SMD}}$ for temperate deciduous tree species in East Asia. The $f_{\mathrm{SMD}}$ values were not calculated in this study $\left(f_{\mathrm{SMD}}=1\right)$, although this assumption would lead to an overestimation of stomatal ozone uptake. Even so, the results would still allow a comparison of the maps between stomatal ozone uptake and AOT40 because many areas in East Asia have a large amount of precipitation in summer. Therefore, the effects of water stress on stomatal ozone uptake were estimated using only the $f_{\mathrm{VPD}}$ values.

\subsection{Estimation of stomatal ozone uptake}

Estimation of stomatal ozone uptake $\left(F_{\text {st }} ;\right.$ nmol $\left.\mathrm{O}_{3} \mathrm{~m}^{-2} \mathrm{~s}^{-1}\right)$ were calculated based on the assumption that the ozone concentration at the top of the canopy $\left(C\left(z_{1}\right), \mathrm{nmol} \mathrm{m}^{-3}\right)$ represented a concentration near sunlit leaves at the top of the canopy (Emberson et al. 2007). We used ozone 
Table 1 Parameters of the stomatal conductance model for each forest type in East Asia

\begin{tabular}{|c|c|c|c|c|}
\hline \multirow{2}{*}{$\begin{array}{l}\text { Parameter } \\
g_{\max }\left(\mathrm{mmol} \mathrm{m}^{-2} \mathrm{~s}^{-1}\right)\end{array}$} & \multirow{2}{*}{\multicolumn{2}{|c|}{$\frac{\text { Dominant species }}{\text { Beech (CDF), oak (CMF and WDF) }}$}} & \multirow{3}{*}{$\begin{array}{l}\text { Additional species } \\
\text { Birch (CMF) } \\
680 \\
\text { (CMF: B. ermanii }\end{array}$} & \multirow{3}{*}{$\begin{array}{l}\text { Reference } \\
\text { Tanaka et al. (1998) } \\
\text { Sirisampan et al. (2003) } \\
\text { Iio et al. (2004) } \\
\text { Xin and Guo (2004) } \\
\text { Muraoka and Koizumi (2005) } \\
\text { Yamazaki et al. (2006) }\end{array}$} \\
\hline & & & & \\
\hline$g_{\max }\left(\mathrm{mmol} \mathrm{m} \mathrm{m}^{-2} \mathrm{~s}^{-1}\right)$ & $\begin{array}{l}425 \\
\text { (CDF: F. crenata) }\end{array}$ & $\begin{array}{l}385 \\
(\mathrm{CMF}: Q . \text { crispula }) \\
430 \\
(\mathrm{WDF}: Q . \text { serrata; } Q . \text { liaotungensis) }\end{array}$ & & \\
\hline$f_{\text {light_} \_.5}\left(\mu \mathrm{mol} \mathrm{m} \mathrm{m}^{-2} \mathrm{~s}^{-1}\right)$ & 90 & 145 & 110 & $\begin{array}{l}\text { Tanaka et al. (1998) } \\
\text { Sirisampan et al. (2003) } \\
\text { lio et al. (2004) } \\
\text { Yamazaki et al. (2006) }\end{array}$ \\
\hline $\mathrm{T}_{\text {opt }}$ & 25 & 24 & 25 & Tanaka et al. (1998) \\
\hline $\mathrm{T}_{\min }$ & 0 & 0 & 0 & Iio et al. (2004) \\
\hline $\mathrm{T}_{\max }\left({ }^{\circ} \mathrm{C}\right)$ & 40 & 48 & 45 & Yamazaki et al. (2006) \\
\hline $\begin{array}{l}f_{\mathrm{VPD} \_0.5} \\
(\mathrm{kPa})\end{array}$ & 2.4 & 2.3 & 1.2 & $\begin{array}{l}\text { Iio et al. (2004) } \\
\text { Xin and Guo (2004) }\end{array}$ \\
\hline$\alpha$ & 1.9 & 3.5 & 2.5 & Yamazaki et al. (2006) \\
\hline
\end{tabular}

CMF: cool-temperate mixed broadleaf/conifer forest; CDF: cool-temperate deciduous forest; WDF: warm-temperate deciduous forest)

concentration data at $20 \mathrm{~m}$ high as $C\left(z_{1}\right)$. Then stomatal ozone uptake was calculated as:

$F_{s t}=C\left(z_{1}\right) \cdot\left\{1 /\left(r_{b}+r_{c}\right)\right\} \cdot\left\{\left(g_{s w} / 1.65\right) /\left(g_{s w} / 1.65+g_{\text {ext }}\right)\right\}$

where $r_{\mathrm{b}}$ is the leaf boundary layer resistance $\left(\mathrm{s} \mathrm{m}^{-1}\right), r_{\mathrm{c}}$ is the leaf surface resistance $\left(=1 /\left(g_{\mathrm{sw}} / 1.65+g_{\text {ext }}\right) ; \mathrm{s} \mathrm{m}^{-1}\right)$, 1.65 accounts for the difference in diffusivity of water in air compared with ozone, and $g_{\text {ext }}$ is the external leaf or cuticular conductance $\left(\mathrm{s} \mathrm{m}^{-1}\right) \cdot g_{\text {ext }}$ was set to $0.0004 \mathrm{sm}^{-1}$ (Emberson et al. 2007).

Leaf boundary layer resistance $\left(r_{\mathrm{b}}\right)$ was calculated from the wind speed at canopy height, $u\left(z_{l}\right)\left(\mathrm{m} \mathrm{s}^{-1}\right)$, and the mean leaf width, $L_{\mathrm{d}}(\mathrm{m})$ (UNECE 2004):

$r_{b}=1.3 \cdot 150 \cdot\left\{L_{d} / u\left(z_{1}\right)\right\}^{0.5}$

where the factor 1.3 accounts for differences in diffusivity between heat and ozone. $L_{\mathrm{d}}$ for oak and beech/birch were determined as 0.1 and $0.05 \mathrm{~m}$, respectively, from leaf shape data in Japan (Endo 1940).

In Europe, the accumulative stomatal ozone uptake $\left(\mathrm{AF}_{\mathrm{st}} \mathrm{Y}\right)$ was recommended to assess the ozone risk for forest species (Karlsson et al. 2007). It is given by:

$A F_{s t} Y=\int\left(F_{s t}-Y\right) \cdot d t$

where $\mathrm{Y}$ is a threshold of stomatal ozone uptake $\left(\mathrm{nmol} \mathrm{O} \mathrm{O}_{3}\right.$ $\mathrm{m}^{-2} \mathrm{~s}^{-1}$ ). In Europe, the threshold of $F_{\mathrm{st}}$ (represented as $\mathrm{Y}$ ) is currently used (Emberson et al. 2007; Karlsson et al. 2007). However, it is not clear whether the same threshold of $\mathrm{F}_{\mathrm{st}}$ can be applied in East Asia. Therefore, we did not set a threshold for the $\mathrm{F}_{\mathrm{st}}$ value $\left(\mathrm{AF}_{\mathrm{st}} \mathrm{O}\right)$ in the present study.

\subsection{Estimation of leaf duration}

Leaf duration was estimated by using a phenological model of leaf development. The beginning and end of the leaf duration were estimated using the temperature dependent method (White et al. 1997; Botta et al. 2000). In this method, Botta et al. (2000) estimated the date of leaf onset as a function of the number of growing degree-days (GDD) and the number of chilling days for cool biomes around the world. GDD is given by:

$G D D=\sum_{J a n .1}^{t} \max \left(T_{d a y}-5,0\right)$

where $T_{\text {day }}$ is the daily mean temperature $\left({ }^{\circ} \mathrm{C}\right)$ and $t$ represents the day of the year (DOY). The leaf duration starts when the number of GDD after 1 January exceeds a critical value $\left(\mathrm{GDD}_{\mathrm{CV}}\right)$, which is expressed as an exponential function of the number of chilling days (NCD) after 1 November in the previous year. A chilling day has a daily mean air temperature below $5^{\circ} \mathrm{C}$. GDD $\mathrm{CV}$ is given by:

$G D D_{C V} \geq-68+638 \exp (-0.01 N C D)$ 
White et al. (1997) used satellite data and observed phenology to show that the leaf duration in the United States ends when the day length drops to less than $11 \mathrm{~h}$ and the soil temperature is $\leq 11^{\circ} \mathrm{C}$, or when the soil temperature falls below $2^{\circ} \mathrm{C}$ regardless of day length.

By adopting these two approaches, we could estimate the beginning and end of the leaf duration from climate data in East Asia.

\subsection{Input data}

To estimate stomatal ozone uptake in East Asia, we needed distribution data for deciduous forest types, climate data, and ozone concentration data. The distributions of deciduous forest types were assumed using potential distributions of each deciduous forest type based on the warmth index (WI) in China (Fang and Yoda 1990), and using a threshold of annual precipitation of $600 \mathrm{~mm}$ year $^{-1}$ (Woodward and Williams 1987). Fang and Yoda (1990) showed correlations between the forest type in China and the thermal climate by using WI, which was calculated from monthly mean temperature:

$W I=\sum_{1}^{12} \max \left(T_{\text {month }}-5,0\right)$

where $\mathrm{T}_{\text {month }}$ is the monthly mean temperature $\left({ }^{\circ} \mathrm{C}\right)$ in month $i$. Fang and Yoda (1990) reported that distributions of CMF and CDF, and WDF could be estimated by WI values between $50^{\circ} \mathrm{C}$ month and $90^{\circ} \mathrm{C}$ month, and between $90^{\circ} \mathrm{C}$ and $135^{\circ} \mathrm{C}$ month, respectively.
Furthermore, Nakashizuka and Iida (1995) reported that temperate deciduous forest trees generally covered the areas from $30^{\circ} \mathrm{N}$ to $50^{\circ} \mathrm{N}$ in East Asia, except for Inner Mongolia. Most of Inner Mongolia is covered by desert, and the rest is grassland. Therefore, the study area included estimated deciduous forest types based on $W I$ between $30^{\circ} \mathrm{N}$ and $45^{\circ} \mathrm{N}$, and between $100^{\circ} \mathrm{E}$ and $145^{\circ} \mathrm{E}$, except for Inner Mongolia (Fig. 2).

Climate data (air temperature, soil temperature, air humidity, solar radiation and wind speed) and ozone concentration data from the year 2000 (Takigawa et al. 2007) were input into our model. These data were estimated using CHASER (Sudo et al. 2002) and the WRF/Chem model (Grell et al. 2005) provided at $6 \mathrm{~h}$ temporal resolution and a spatial resolution of $40 \times 40 \mathrm{~km}$ across East Asia. The estimation of stomatal ozone uptake was conducted in each grid square $(40 \times 40 \mathrm{~km}, n=1420)$ with $6 \mathrm{~h}$ time steps.

\section{Results}

\subsection{Estimates for beginning and end of the leaf duration}

Figure 3 shows a comparison of the observed versus estimated beginning and end of the leaf duration. Although the leaf duration was generally shorter in the north, the leaf duration did not always vary with latitude. For example, at the site in northern Japan $\left(39^{\circ} 78^{\prime} \mathrm{N}\right)$, the growing season was shorter than that at Beijing $\left(40^{\circ} 01^{\prime} \mathrm{N}\right)$. This finding indicates that the leaf duration is not a simple function of
Fig. 2 Estimated distribution for each forest type in East Asia

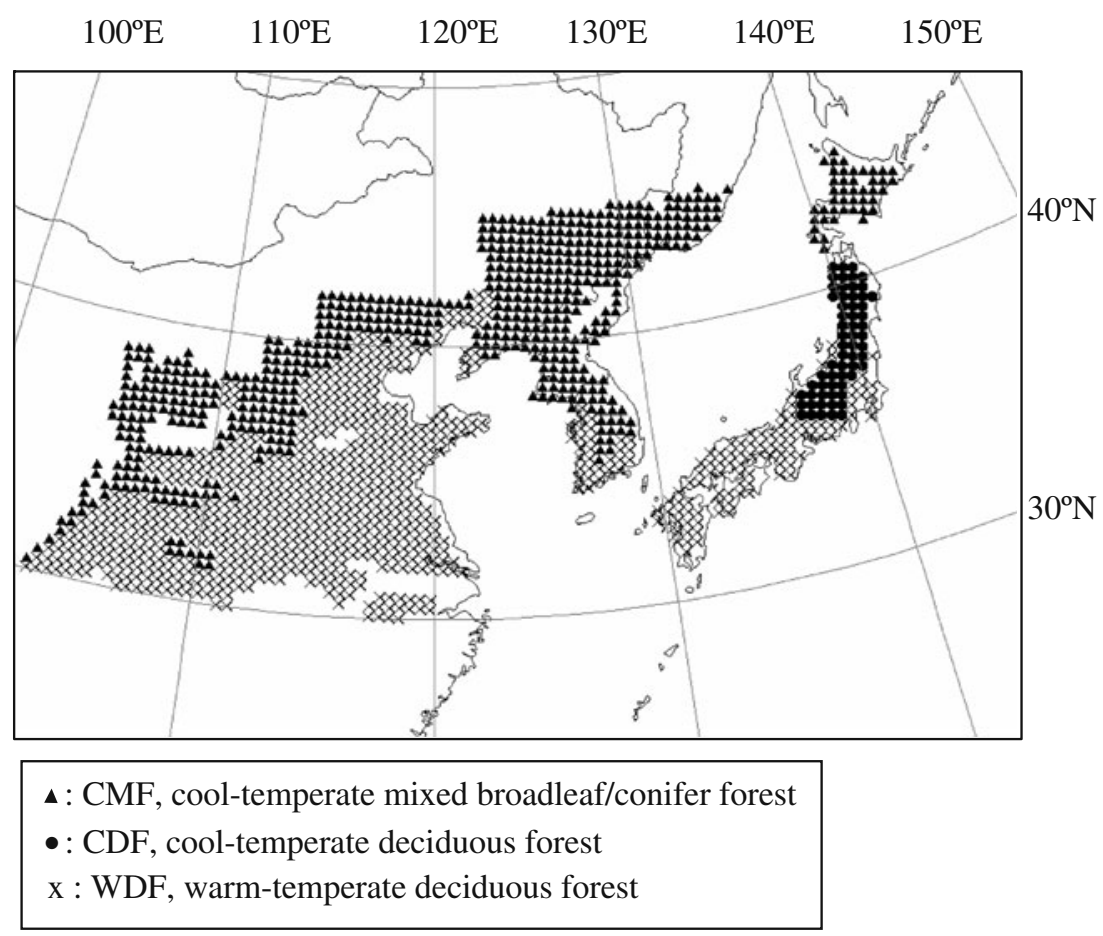


a

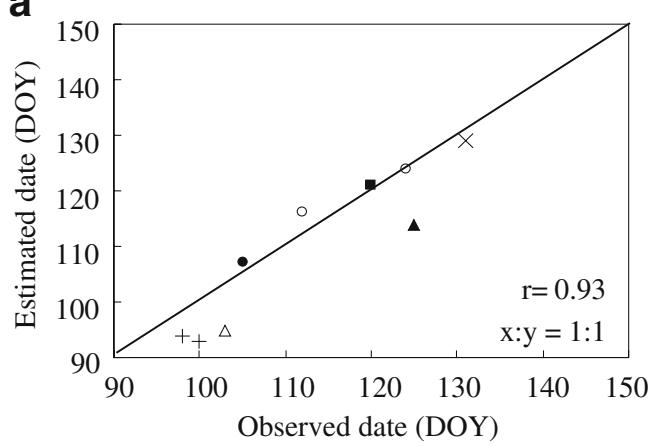

b

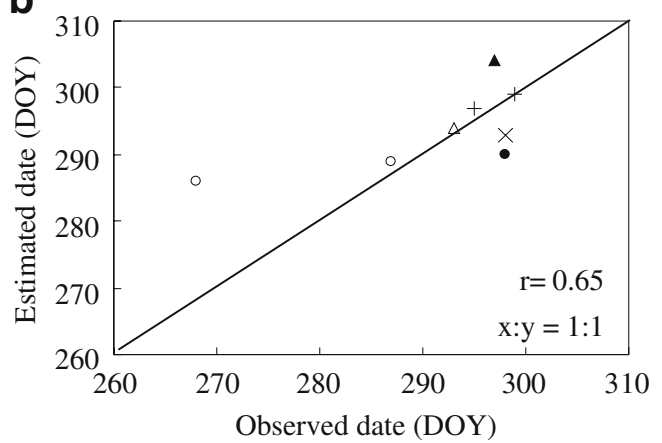

O :Averaged data from 1982 to 1993 in northeastern China (Chen et al., 2005). - :Averaged data from 1982 to 1993 in Beijing (Chen et al., 2005).

$\triangle$ :Averaged data from 1982 to 1993 in northern China (Chen et al., 2005). + :Averaged data from 1982 to 1993 in central China (Chen et al., 2005).

$X$ :Averaged data of 9 species in northern Japan (Aoki and Hashimoto, 1995)

: Averaged data from 1996 to 2001 in northern Korea (Kang et al., 2003)

$\boldsymbol{\Delta}$ :Averaged data from 1998 to 2002 in central Japan (Kato and Hayashi, 2008)

Fig. 3 Comparisons of observed versus estimated beginning (a) and end (b) of the leaf duration. Northern Korean data showed only beginning of the leaf duration. The other data showed both beginning and end of the leaf duration

location. To estimate the leaf duration, regional environmental conditions should be considered. Therefore, advanced approaches such as the temperature dependent method are appropriate to estimate the leaf duration.

The phenological model did not accurately estimate the end of the leaf duration in northeastern China (Mudanjiang: $\left.44^{\circ} 26^{\prime} \mathrm{N}, 129^{\circ} 40^{\prime} \mathrm{E}\right)$. However, the model estimated the beginning and end of the leaf duration fairly well in other regions (Fig. 3). Based on these results, the model was able to estimate the beginning and end of the leaf duration in a wide area with an acceptable accuracy for estimation of stomatal ozone uptake.

\subsection{Comparison between the AOT40 and $\mathrm{AF}_{\mathrm{st}} 0$ maps in East Asia}

Figure 4a shows a map of the AOT40 values from April to September. Our main finding was the large differences in the AOT40 values among regions. The AOT40 values were high in western Japan $\left(30^{\circ}-35^{\circ} \mathrm{N}, 130^{\circ}-135^{\circ} \mathrm{E}\right)$, southern
Korea $\left(35^{\circ} \mathrm{N}, 125^{\circ}-130^{\circ} \mathrm{E}\right)$, and northeastern and central China $\left(40^{\circ}-42^{\circ} \mathrm{N}, 123^{\circ}-125^{\circ} \mathrm{E} ; 30^{\circ}-35^{\circ} \mathrm{N}, 110^{\circ} \mathrm{E}\right.$ respectively). In these areas, the AOT40 values reached more than $30,000 \mathrm{ppb} \bullet \mathrm{h}$. Meanwhile, the AOT40 values were low $(0$ $10,000 \mathrm{ppb} \cdot \mathrm{h})$ in Hokkaido $\left(42^{\circ}-44^{\circ} \mathrm{N}, 140^{\circ}-145^{\circ} \mathrm{E}\right)$. Using the AOT40 values, Kohno et al. (2005) estimated that the critical level of ozone for highly sensitive deciduous tree species in East Asia was 8,000-15,000 ppb•h from April to September, this level corresponded to a $10 \%$ growth reduction. In this study, AOT40 values of more than $15,000 \mathrm{ppb} \cdot \mathrm{h}$ were found across $83 \%$ of the study area.

Figure $4 \mathrm{~b}$ shows the accumulative stomatal ozone uptake $\left(\mathrm{AF}_{\mathrm{st}} \mathrm{O}\right)$ during the leaf duration in dominant temperate deciduous forest tree species in East Asia. Relatively high $\mathrm{AF}_{\mathrm{st}} \mathrm{O}$ values $\left(>40 \mathrm{mmol} \mathrm{m}{ }^{-2}\right)$ were estimated in central China $\left(30^{\circ}-35^{\circ} \mathrm{N}, 110^{\circ} \mathrm{E}\right)$, southern Korea $\left(35^{\circ} \mathrm{N}, 125-\right.$ $\left.130^{\circ} \mathrm{E}\right)$, and western and central Japan $\left(30^{\circ}-35^{\circ} \mathrm{N}, 130^{\circ}-\right.$ $\left.135^{\circ} \mathrm{E}\right)$. Within the study area, the $\mathrm{AF}_{\mathrm{st}} \mathrm{O}$ values were highest $\left(>45 \mathrm{mmol} \mathrm{m} \mathrm{m}^{-2}\right)$ in central China and western Japan. These areas experienced high ozone concentrations in spring and summer. In addition, these areas have a wet climate in the summer (Fig. 5). These results suggest that the warm and wet climate enhanced stomatal conductance, leading to stomatal ozone uptake.

Meanwhile, in eastern China $\left(35^{\circ} \mathrm{N}, 115^{\circ}-117^{\circ} \mathrm{E}\right)$, the $\mathrm{AF}_{\mathrm{st}} 0$ values were much lower than those in other areas, because eastern China experienced severe drought in 2000 (Wang et al. 2003). In eastern China, the $f_{\mathrm{VPD}}$ values were less than 0.7 in the summer (Fig. 5). Because high VPD reduced stomatal conductance, stomatal ozone uptake was limited. In this study, the effects of soil water stress on stomatal conductance were not considered in the estimation of stomatal ozone uptake. Stomatal ozone uptake would be much more limited by soil water stress in areas such as eastern China that experienced drought events.

In northeastern China $\left(40^{\circ}-42^{\circ} \mathrm{N} 123-125^{\circ} \mathrm{E}\right)$, the $\mathrm{AF}_{\mathrm{st}} 0$ values were relatively low although the AOT40 values were very high. In this area, the $f_{\mathrm{VPD}}$ values showed that VPD did not affect stomatal conductance very much during the summer (Fig. 5). Stomatal limitation during the summer did not affect the $\mathrm{AF}_{\mathrm{st}} \mathrm{O}$ values very much in this area. However, $\mathrm{AF}_{\mathrm{st}} \mathrm{O}$ values were calculated as the sum of stomatal ozone uptake during the leaf duration, and in this area the leaf duration was shorter than in other areas (Fig. 3). Therefore, the $\mathrm{AF}_{\mathrm{st}} \mathrm{O}$ values were estimated to be relatively low because of the shorter leaf duration in northeastern China.

The comparison between the AOT40 and $\mathrm{AF}_{\text {st }} 0$ maps (Fig. 4a, b) suggested that the areas where the AOT 40 values were $\operatorname{high}(>20,000 \mathrm{ppb} \bullet \mathrm{h})$, were not always high $\mathrm{AF}_{\mathrm{st}} 0$ areas. This result suggests that ozone risk assessment using AOT40 would overestimate the ozone risks for temperate deciduous forest trees. 
Fig. 4 Comparison between (a) AOT40 (accumulative exposure above a threshold concentration of $40 \mathrm{ppb}$ during daylight hours) and (b) $\mathrm{AF}_{\mathrm{st}} \mathrm{O}$ (accumulative stomatal ozone uptake) maps of temperate deciduous forest trees in East Asia
Fig. 5 Spatial distribution of averaged $f_{\mathrm{VPD}}$ values from July to August in East Asia. $f_{\mathrm{VPD}}$ shows the response of stomatal conductance to vapor pressure deficit, scaled from 0 to 1
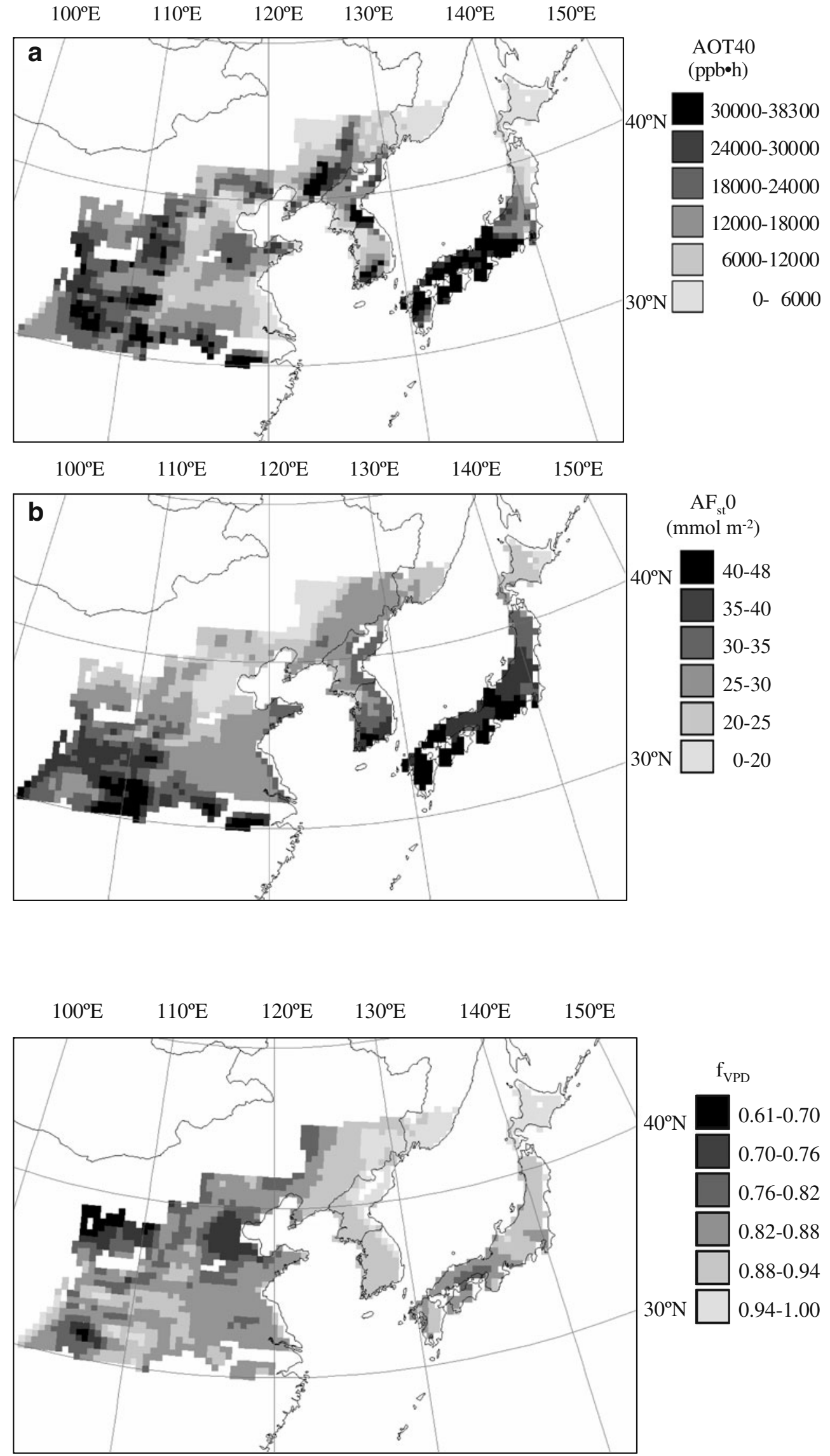


\section{3 $\mathrm{AF}_{\mathrm{st}} 0$ of the species in each forest type}

The relationships between $\mathrm{AOT} 40$ and $\mathrm{AF}_{\mathrm{st}} 0$ were analyzed for each forest type (Table 2).

In the CDF region, the correlation between AOT40 and $\mathrm{AF}_{\mathrm{st}} 0$ was very high because the humid climate did not limit stomatal ozone uptake.

However, in the other two regions, the correlation between $\mathrm{AOT} 40$ and $\mathrm{AF}_{\mathrm{st}} \mathrm{O}$ was lower; the correlation between AOT40 and $\mathrm{AF}_{\mathrm{st}} \mathrm{O}$ was especially low in CMF region (Table 2). In both the WDF and CMF regions, there were areas such as eastern China that experienced summer drought (Fig. 5). The $f_{\mathrm{VPD}}$ values showed that VPD affected stomatal conductance in summer in these areas. Therefore, summer drought was a factor influencing a difference between the two indices (AOT40 and $\mathrm{AF}_{\mathrm{st}} 0$ ) in these regions. Furthermore, in the CMF region, the AOT40 values were quite low in Hokkaido $\left(42^{\circ}-44^{\circ} \mathrm{N}, 140^{\circ}-145^{\circ}\right.$ E) and were very high in northeastern China $\left(40^{\circ}-42^{\circ} \mathrm{N}\right.$, $123^{\circ}-125^{\circ} \mathrm{E}$ ), but much less difference was seen in the $\mathrm{AF}_{\mathrm{st}} \mathrm{O}$ values for deciduous oak between these two regions (Fig. 4).

To investigate the effect of differences in species-specific stomatal conductance parameters on the $\mathrm{AF}_{\mathrm{st}} \mathrm{O}$ values, additional calculations of stomatal ozone uptake were conducted using the parameters of birch species found in the CMF (Table 1). In birch species, there was little correlation between $\mathrm{AOT} 40$ and $\mathrm{AF}_{\mathrm{st}} \mathrm{O}$ (Table 2). For instance, in Hokkaido $\left(42^{\circ}-44^{\circ} \mathrm{N}, 140^{\circ}-145^{\circ} \mathrm{E}\right)$, the $\mathrm{AF}_{\mathrm{st}} 0$ values of birch were moderately high $\left(30 \mathrm{mmol} \mathrm{m}^{-2}\right.$ on average) in spite of the very low AOT40 values $\left(5,000 \mathrm{ppb} \bullet \mathrm{h}\right.$ on average). The estimate of the $\mathrm{AF}_{\mathrm{st}} 0$ was similar in northeastern China, where the AOT40 values were high. In birch species, stomatal conductance parameters were quite different from the parameters for deciduous oak and beech (Table 1). The value of $g_{\max }$ for birch was high, and $f_{\mathrm{VPD} \_0.5}$ showed that stomatal conductance for birch was very sensitive to VPD. Therefore, the result would be related to the characteristics of the stomatal conductance parameters. Hokkaido has a cool and humid

Table 2 Correlation between AOT40 (accumulative exposure above a threshold concentration of $40 \mathrm{ppb}$ during daylight hours) and $\mathrm{AF}_{\mathrm{st}} 0$ (accumulative stomatal ozone uptake) for each forest type in East Asia. All of these correlations are statistically significant at the $1 \%$ level

\begin{tabular}{lll}
\hline Forest type (species) & Pearson's correlation & Number grids ${ }^{1}$ \\
\hline CDF (beech) & 0.97 & 61 \\
CMF (deciduous oak) & 0.52 & 619 \\
CMF (birch) & 0.15 & 619 \\
WDF (deciduous oak) & 0.65 & 740 \\
\hline
\end{tabular}

${ }^{1}$ Number of $40 \times 40 \mathrm{~km}$ grids in which the indicated forest type was found climate (Fig. 5). An interaction between these conditions and the characteristics of stomatal conductance enhanced the stomatal ozone uptake in Hokkaido, although this region had a relatively low ozone concentration. This result suggested that the $\mathrm{AF}_{\mathrm{st}} 0$ values were regulated not only by ozone concentration but also by the interaction between climate factors and species-specific stomatal conductance parameters. Therefore, the two indices would suggest different result of ozone risks in the CMF region.

\section{Discussion}

The main objective of our study was to compare the $\mathrm{AF}_{\mathrm{st}} 0$ and AOT40 values for deciduous forest trees in East Asia. Simpson et al. (2007) similarly compared the spatial distribution of the $\mathrm{AF}_{\mathrm{st}} 1.6\left(\mathrm{Y}=1.6 \mathrm{nmol} \mathrm{m} \mathrm{m}^{-2} \mathrm{~s}^{-1}\right)$ and AOT40 values in Europe. The AOT40 value was high in southern Europe, whereas values were lower in northern Europe. The spatial gradient of the AOT40 values was remarkable from south to north, but the spatial gradient of the $\mathrm{AF}_{\mathrm{st}} 1.6$ values was much less mainly for two reasons. First, stomatal ozone uptake was limited due to drought stress during the summer in Mediterranean regions, where ozone concentrations were high (Paoletti 2006). Second, the climate conditions in northern Europe were favorable for stomatal ozone uptake, even though ozone concentrations in this region were lower than in southern Europe (Simpson et al. 2007).

In this study, the $\mathrm{AF}_{\mathrm{st}} \mathrm{O}$ values showed much greater regional differences than were seen in Europe. In western Japan and central China, the $\mathrm{AF}_{\mathrm{st}} 0$ values were very high in the study area (Fig. 4b). These areas of high ozone concentration corresponded to the areas where stomatal ozone uptake was estimated to be high because of the humid climate.

On the other hand, the results of this study for the CMF region were similar to those seen in northern Europe. In Hokkaido, favorable climate conditions for stomatal conductance enhanced the stomatal ozone uptake. In this region, the $\mathrm{AF}_{\mathrm{st}} 0$ values were moderately high in spite of the very low AOT40 values, especially in birch species.

In this study, the $\mathrm{AF}_{\mathrm{st}} 0$ values were influenced by ozone concentrations, regional characteristics such as climate conditions and leaf duration, and stomatal conductance parameters. One of the regional characteristics we studied was the leaf duration. In western Japan and central China, the leaf duration was estimated to be long because of the warm climate (Fig. 3). The leaf duration in these areas was estimated to be about 40-60 days longer than that in northeastern China. These differences in the leaf duration potentially changed the estimates of $\mathrm{AF}_{\mathrm{st}} \mathrm{O}$ values. However, the AOT40 values were similar among western 
Japan and central China and northeastern China (Fig. 4a) because the AOT40 values were calculated over a fixed time period (April-September). Using a phenological model, the regional characteristics of the leaf duration could be reflected in the $\mathrm{AF}_{\mathrm{st}} 0$ values.

Ozone risk assessment using AOT40 assumes that the ozone impacts on plants increases with increasing ozone concentrations. This assumption is almost correct. However, other factors affect the impact of ozone on plants. The result of this study illustrated some of the limitations of performing ozone risk assessment using AOT40.

For example, when leaf duration is longer, leaves experience a longer period of ozone exposure. In general, ozone concentration is known to induce negative effects on stomatal conductance. Pleijel et al. (2002) and Danielsson et al. (2003) reported that high ozone exposure over a long time caused a decline in $g_{\max }$ for crops in their modeling studies. In western Japan and central China, long exposure to high ozone concentrations would also be expected to induce negative effects on stomatal conductance of temperate deciduous forest trees. The $\mathrm{AF}_{\mathrm{st}} \mathrm{O}$ values would be estimated to be lower in these regions. However, the effects of ozone on stomatal conductance $\left(f_{\mathrm{O} 3}\right)$ were not included in our stomatal conductance model, suggesting that the values for $\mathrm{AF}_{\mathrm{st}} \mathrm{O}$ were overestimated in the present study. Therefore, including the parameter $f_{\mathrm{O} 3}$ would be expected to improve the ozone uptake modeling for deciduous forests in East Asia.

Previous studies (e.g., Paoletti and Manning 2007) suggested that the stomatal flux-based approach is adequate on scientific background, and would be a useful tool for ozone risk assessment in East Asia. However, little work had been done to develop the stomatal flux-based approach for East Asia, even though stomatal ozone uptake was a focus for assessing ozone damage more than 3 decades ago (Omasa et al. 1979). To further develop the stomatal fluxbased approach, a great deal of effort will be needed. In East Asia, measurements of ozone flux, including dry deposition of ozone, have begun recently (Matsuda et al. 2007). In the future, more work is needed to validate and improve our model with field measurements.

Acknowledgements This work was supported by JSPS Fellowships for Young Scientists and was partly supported by the Global Environment Research Fund (C-062) of the Ministry of the Environment, Japan.

\section{References}

Aoki Y, Hashimoto R (1995) Leaf phenology of woody plant species in a cool-temperate secondary forest of Quercus serrata. Bull Iwate Univ Forests 26:29-41 (in Japanese)

Ashmore MR (2005) Assessing the future global impacts of ozone on vegetation. Plant Cell Environ 28(8):949-964
Botta A, Viovy N, Ciais P, Friedlingstein P, Monfray Y (2000) A global prognostic scheme of leaf onset using satellite data. Glob Chang Biol 6:709-725

Chen Y, Hu B, Yu R (2005) Spatial and temporal variation of phenological growing season and climate change impacts in temperate eastern China. Glob Chang Biol 11:1118-1130

Danielsson H, Karlsson GP, Karlsson PE, Pleijel H (2003) Ozone uptake modeling and flux-response relationship - an assessment of ozoneinduced yield loss in spring wheat. Atmos Environ 37:475-485

Emberson LD, Buker P, Ashmore MR (2007) Assessing the risk caused by ground level ozone to European forest trees: a case study in pine, beech and oak across different climate regions. Environ Pollut 147(3):454-466

Endo S (1940) A Pleistocene flora from Siobara, Japan. Sci Rep Tohoku Imp Univ, 2nd series Geol 21:47-A24

Estrella N, Menzel A (2006) Responses of leaf colouring in four deciduous tree species to climate and weather in Germany. Clim Res 32(3):253-267

Fang J, Yoda K (1990) Climate and vegetation in China. IV. Distribution of tree species along thermal gradient. Ecol Res 5:291-302

Grell GA, Peckham SE, Schmitz R, McKeen SA, Frost G, Skamarock WC, Eder B (2005) Fully coupled "online" chemistry within the WRF model. Atmos Environ 39(37):6957-6975

Iio A, Fukasawa H, Nose Y, Kakubari Y (2004) Stomatal closure induced by high vapor pressure deficit limited midday photosynthesis at the canopy top of Fagus crenata Blume on Naeba Mountain in Japan. Trees 18(5):510-517

Izuta T, Matsumura H, Kohno Y, Shimuzu H (2001) Experimental studies on the effects of ozone on forest tree species. J Jpn Soc Atmos Environ 36(2):60-77, (in Japanese with English summary)

Jarvis PG (1976) Interpretation of variations in leaf water potential and stomatal conductance found in canopies in field. Phil Trans R Soc Lond B 273(927):593-610

Kang S, Running SW, Lim JH, Zhao M, Park CR, Loehman R (2003) A regional phenology model for detecting onset of greenness in temperate mixed forests, Korea: an application of MODIS leaf area index. Remote Sens Environ 86: 232-242

Karlsson PE, Braun S, Broadmeadow M, Elvira S, Emberson L, Gimeno BS, Le Thiec D, Novak K, Oksanen E, Schaub M, Uddling J, Wilkinson M (2007) Risk assessments for forest trees: the performance of the ozone flux versus the AOT concepts. Environ Pollut 146(3):608-616

Kato J, Hayashi I (2008) Phenological studies of deciduous trees in the cool temperate region of Japan. J Ecol Field Biol 31:193-200

Kohno Y, Matsumura H, Ishii T, Izuta T (2005) Establishing critical levels of air pollutants for protecting East Asian vegetation - a challenge. In: Omasa K, Nouchi I, De Kok LJ (eds) Plant responses to air pollution and global change. Springer, Tokyo, pp $243-250$

Maruyama K, Honda M (1993) Stomatal responses in Fagus crenata. Quercus crispula and Q. serrata seedlings. Res Bull Niigata Univ For 26:75-88 (in Japanese with English summary)

Matsuda K, Takahashi A, Hayashi K, Sorimachi A (2007) A review of field studies on dry deposition in East Asia. J Jpn Soc Atmos Environ 42:261-270 (in Japanese with English summary)

Muraoka H, Koizumi H (2005) Photosynthetic and structural characteristics of canopy and shrub trees in a cool-temperate deciduous broadleaved forest: implication to the ecosystem carbon gain. Agric For Meteorol 134(1-4):39-59

Naja M, Akimoto H (2004) Contribution of regional pollution and long-range transport to the Asia-Pacific region: analysis of longterm ozonesonde data over Japan. J Geophys Res 109:D21306. doi:21310.21029/22004JD004687

Nakashizuka T, Iida S (1995) Composition, dynamics and disturbance regime of temperate deciduous forests in Monsoon Asia. Vegetatio 121(1-2):23-30 
NIES (1980) Studies on the effects of air pollutants on plants and mechanisms of phytoxicity. Res Rep Natl Inst Environ Stud, Japan, 265 pages

NIES (1984) Studies on effects of air pollutant mixtures on plants, Parts $1 \&$ 2.Res Rep Natl Inst Environ Stud, Japan, 163 and 155 pages

Omasa K, Abo F, Natori T, Totsuka T (1979) Studies of air pollutant sorption by plants. (II) Sorption under fumigation with $\mathrm{NO}_{2}, \mathrm{O}_{3}$ or $\mathrm{NO}_{2}+\mathrm{O}_{3}$. J Agric Met 35:77-83 (in Japanese with English summary)

Omasa K, Tobe K, Kondo T (2002) Absorption of organic and inorganic air pollutants by plants. In: Omasa K, Saji H, Youssefian N, Kondo N (eds) Air pollution and plant biotechnology. Springer, Tokyo, pp 155-178

Paoletti E (2006) Impact of ozone on Mediterranean forests: a review. Environ Pollut 144(2):463-474

Paoletti E, Manning WJ (2007) Toward a biologically significant and usable standard for ozone that will also protect plants. Environ Pollut 150(1):85-95

Pleijel H, Danielsson H, Vandermeiren K, Blum C, Colls J, Ojanpera $\mathrm{K}$ (2002) Stomatal conductance and ozone exposure in relation to potato tuber yield: - results from the European CHIP programme. Eur J Agron 17(4):303-317

Simpson D, Ashmore MR, Emberson L, Tuovinen JP (2007) A comparison of two different approaches for mapping potential ozone damage to vegetation. a model study. Environ Pollut 146 (3):715-725

Sirisampan S, Hiyama T, Takahashi A, Hashimoto T, Fukushima Y (2003) Diurnal and seasonal variations of stomatal conductance in a secondary temperate forest. J Jpn Soc Hydrol Water Resour 16:113-130 (in Japanese with English summary)
Sudo K, Takahashi M, Kurokawa J, Akimoto H (2002) CHASER: a global chemical model of the troposphere - 1. Model description. J Geophys Res 107(D17):4339

Takigawa M, Niwano M, Akimoto H, Takahashi M (2007) Development of a one-way nested global-regional air quality forecasting model. SOLA 3:81-84

Tanaka K, Kosugi Y, Ohte N, Kobashi S, Nakamura A (1998) Model of $\mathrm{CO} 2$ flux between a plant community and atmosphere, and simulation of CO2 flux over a planted forest. Jpn J Ecol 48:265286 (in Japanese with English summary)

UNECE (2004) Manual on methodologies and criteria for modelling and mapping critical loads and levels and air pollution effects, risks and trends. Chapter 3: mapping critical levels for vegetation. Umweltbundesamt, Berlin, pp 1-52

Wang Z, Zhai P, Zhang H (2003) Variation of drought over northern China during 1950-2000. J Geograph Sci 13(4):480-487

White MA, Thornton PE, Running SW (1997) A continental phenology model for monitoring vegetation responses to interannual climatic variability. Global Biogeochem Cycles 11(2):217-234

Woodward FI, Williams BG (1987) Climate and plant-distribution at global and local scales. Vegetation 69(1-3):189-197

Xin SH, Guo SW (2004) Simulations and analysis of net primary productivity in Quercus liaotungensis forest of Donglingshan mountain range in response to different climate change scenarios. Acta Bot Sin 46:1281-1291

Yamazaki T, Kato K, Kuwada T, Nakai T, Park H, Ohta T (2006) Land surface model simulation on CREST forest sites using measured leaf-scale physiological parameters. In: International workshop on $\mathrm{H} 2 \mathrm{O}$ and $\mathrm{CO} 2$ exchanges in Siberia. Amsterdam, pp. 81-84 